\author{
O.Ya. Mezenova ${ }^{1}$, H. Morovvati ${ }^{2}$, S. Keshtkar ${ }^{1}$, E. Romiani ${ }^{2 *}$ \\ ${ }^{1}$ Kaliningrad State Technical University, \\ 236022, Kaliningrad, Sovetskiy pr. 1; \\ 2 Tehran University, \\ 1417466191, Tehran, 16th Azar Str., Enghelab Sq.
}

\title{
EXPOSURE OF SPARIDENTEX HASTA TO SALINITY CHALLENGE: A STUDY OF GILL CHLORIDE CELLS AND PLASMA GLUCOSE LEVEL
}

The effects of different water salinities on the number and area of chloride (mitochondriarich) cells and on plasma glucose level in Sparidentex hasta were studied. Fish were exposed to a salinity of 5, 20, 40, and $60 \mathrm{ppt}$ for 14 days. The group kept at $40 \mathrm{ppt}$ was considered as the control. Samples were collected at 6 and $12 \mathrm{~h}$ and on days 1, 2, 7, and 14 of exposure. The results of this study revealed changes in the plasma glucose level and in the number and area of chloride cells in $S$. hasta associated with water salinity variations. It can be concluded that $S$. hasta has a wide tolerance towards salinity changes in the environment, which is provided by the mechanisms of osmoregulation and the involved organs, mostly by gills.

Key words: Sparidentex hasta, water salinity, chloride cells/mitochondria-rich cells, plasma glucose level, extreme habitat adaptation.

DOI: 10.26428/1606-9919-2019-196-63-71.

Мезенова О.Я., Мороввати Х., Кешткар С., Ромиани Э. Воздействие экстремальной солености воды на морского карася Sparidentex hasta: исследование хлоридных клеток в жабрах и уровня глюкозы в плазме крови // Изв. ТИНРО. - 2019. - Т. 196. — С. 63-71.

Рассмотрено влияние различной солености воды на количество и площадь хлоридных клеток в жабрах, а также на уровень глюкозы в плазме крови морского карася Sparidentex hasta. Для этой цели 180 рыб со средней длиной 20-25 см и средней массой 200 г содержались на Исследовательской станции им. Имама Хомейни в течение 14 сут в воде с различной соленостью: $5,20,40$ и 60 ppt. Эксперимент с соленостью воды 40 ppt считался контрольным. В течение эксперимента рыбу кормили коммерческим кормом фирмы Biomar. Отбор проб крови рыбы проводили соответственно через 6 ч, 12 ч, 1 сут, 2, 7 и 14 сут после нахождения в воде с заданным уровнем солености. Исследование жабр и крови осуществляли в лаборатории биотехнологии Университета морской науки и технологии (г. Хоррамшахр, Иран). Измерения уровня глюкозы в плазме (мг/100 мл) проводили колориметрическим методом анализатором Technicon RA1000 (США) с использованием коммерческого набора MAN. Образцы хлоридных клеток в жабрах рыб

* Mezenova Olga Yakovlevna, Doctor of Technical Sciences, Professor of the Department of Food Biotechnology, e-mail: mezenova@klgtu.ru; Morovvati Hassan, Doctor of Biological Sciences, Professor of Department of Histology \& Anatomy, e-mail:hmorovvati@ut.ac.ir; Keshtkar Saeid, Ph.D student of Food Biotechnology Departrment, e-mail: keshtkar.bio@gmail.com; Roomiani Ehsan,Ph.D student of Comparative Histology Department, e-mail: eroomiani@ut.ac.ir.

Мезенова Ольга Яковлевна, доктор технических наук, профессор, e-mail: mеzепоva@klgtu.ru; Мороввати Хасан, доктор биологических наук, профессор, e-mail: hmorovvati@ut.ac.ir; Кешткар Саид, аспирант; e-mail: keshtkar.bio@gmail.com; Ромиани Эхсан, аспирант, е-таil: eroomiani@ut.ac.ir. 
подвергали морфологическим и гистометрическим исследованиям, отмечая особенности клеток, изменение их площади после воздействия воды различной солености, данные сравнивались с данными контрольных образцов. Проанализированы литературные данные, в которых отмечены аналогичные зависимости у других видов рыб. Результаты исследования показали изменения уровня глюкозы, количества и площади хлоридных клеток в жабрах Sparidentex hasta с течением времени и под действием различной солености воды. Установлено, что Sparidentex hasta обладает высокой способностью переносить изменения солености в окружающей среде, что обусловлено физиологическими механизмами осморегуляции и особенностями вовлеченных органов, прежде всего жабр.

Ключевые слова: Sparidentex hasta, соленость воды, хлоридные (митохондриальные) клетки, содержание глюкозы в крови, адаптация к экстремальным условиям.

\section{Introduction}

Life in two environments with different chemical compositions and osmotic pressures and movements between them require a specific compromise and physiological and tissue adaptations for maintaining homeostasis and normal life functions. In fish, some hormonal and enzyme mechanisms, as well as tissue modifications, especially in gills, can be used to regulate osmotic stress for overcoming various stress conditions [Baldisserotto et al., 2007]. Gills are an important organ involved in osmotic regulation, highly sensitive to environmental stress factors and various diseases [Santos et al., 2014]. Gill epithelium consists of different cells, the most important of which are mucosal, squamous, and chloride (mitochondria-rich) cells. Depending on the salinity of the environment, the gill epithelium pumps salt against the osmotic concentration outside or inside the body, which is an activity performed by most of chloride cells [Khuder et al., 2016]. Gills play an important role in keeping ion and acid-base equilibrium in both fresh-water and saline-water environments [Evans et al., 2005]. When moving from fresh water to saline water, euryhaline fish have to change their gills from an ion absorption structure to a secretory structure [Marshall et al., 2002]. The increase in the size and number of chloride cells is one of effective mechanisms of resistance to salinity variations [Uchida et al., 1996].

Water salinity has been studied extensively as one of the environmental factors that have effects on fish of various species [Lisboa et al., 2015]. Variations in salinity level affect the physiological processes in fish [Tahir et al., 2018]. Inside and outside cells, biochemical processes are strongly influenced by salinity variations. As an adaptation to them, marine teleosts actively secrete salt and keep water to maintain homeostasis within the body [Kültz, 2015]. This involves osmoregulation mechanisms that are energy-consuming processes [Lisboa et al., 2015].

The energy required for metabolic processes is provided by energy-rich compounds such as carbohydrates, lipids, and proteins, each of which can be directly used or stored in the body [Jobling, 1994]. Hormones such as catecholamines, glucagon, prolactin, and cortisol are also components of the inborn adaptation of organism to stress. It has been shown that stress in fish triggers an initial response that involves stimulation of the nervous system and increased corticosteroid secretion and catecholamine. Consequently, these initial effects cause a number of physiological changes known as secondary effects [Karşi and Yavuzcan Yildiz, 2005]. One of the major compounds involved in these changes is glucose. Glucose is the most important source of energy used in cellular metabolism, but fish can use other compounds also when exposed to stressful environmental conditions [Lisboa et al., 2015].

The aim of the work was to study the changes in the area and number of chloride cells and the level of glucose in blood plasma of Sparidentex hasta during the exposure to different degrees of salinity in the aquatic environment.

\section{Materials and methods}

To conduct this research, 180 fish with a mean body length of $20-25 \mathrm{~cm}$ and a mean weight of $200 \mathrm{~g}$ were preliminary kept in the same conditions during one week at the Imam Khomeini Marine Research Station (located on the coast of the Persian Gulf) for adaptation. By the end of the adaptation period, the fish were assigned to 12 tanks (15 fish per tank) with the volume of $300 \mathrm{~L}$ filled with water with different salinity levels of 5, 20, 40, and $60 \mathrm{ppt}$ 
for 14 days ( 3 tanks per each salinity level). The group $40 \mathrm{ppt}$ was considered as the control, because the salinity of Persian Gulf water is 39 40 ppt [Moaddab et al., 2017]. Samples were collected at $6 \mathrm{~h}, 12 \mathrm{~h}$ and on days 1, 2, 7, and 14 of exposure. During the experimental period, in order to prevent bacterial contamination and probable fish infections the water, in addition to filtration and UV treatment, was chlorinated and dechlorinated in 2000-liter fiberglass tanks. For this purpose, 24 hours before adding water to the fish storage tanks, chlorine was dissolved at a concentration of $20 \mathrm{ppm}$ and then neutralized by thiosulfate for an hour prior to use [Fielder et al., 2007]. During the experimental period (for two weeks), the physicochemical parameters of water, such as salinity, temperature, $\mathrm{pH}$ and dissolved oxygen, were continuously measured. The photoperiod or light exposure was set at 12 hours and fish were fed with commercial BioMar fish feed.

Sampling of gills and blood. Gill tissues and blood samples were collected at 6 h, 12 hour and on days 1,2, 7, and 14 after the beginning of exposure. After anesthetizing the fish with $0.01 \%$ phenoxyethanol, blood samples were taken. For this purpose, blood was collected by inserting a needle in the posterior part of the fish body, near the caudal peduncle and slightly higher and backward (from 9 fish per each treatment). After sampling, the blood was gently transferred to heparin tubes and kept frozen until centrifugation. Blood samples were centrifuged at $6000 \mathrm{rpm}$ for 8 to 10 minutes. After that, the tubes were gently removed from the centrifuges, and the clear transparent supernatant liquid was collected with a sampler and transferred to 2-mL Eppendorf tubes. Finally, the Eppendorf tubes were transferred to a $-80^{\circ} \mathrm{C}$ freezer of the Biotechnology Laboratory, University of Marine Science and Technology, Khorramshahr, Iran, and kept at this temperature until plasma measurements.

For gill sampling, the second left gill arch was removed and transferred to Bouin's solution (from 9 fish per each treatment). The tissue samples were prepared by using the standard methods for histological study, H\&E stained, and then examined under a light microscope.

Plasma glucose levels. Measurements of plasma glucose level (mg/100 mL) by the colorimetric method were performed on a Technicon RA1000 Analyzer (USA) using a MAN commercial kit [Moron et al., 2003]. For this purpose, $100 \mu \mathrm{L}$ of plasma was used from each sample.

Area and number of chloride cells. For measuring area and number of chloride cells, the Dinolite ${ }^{\circledR}$ software (Dinocapture2.0, version 1.3.2) was used. Area of chloride cells was determined at a magnification of $3000 \times($ Mag. $=3000)$; the area of a selected cell was estimated by using Measurmant tab in Dinocapture 2.0 field screen, based on quantity of pixels. In order to determine the number of chloride cells (in gill filament space), they were counted in 10 images of the filamentous epithelium of 5 consecutive binomial regions (space between 6 lamella) from each fish; in each salinity treatment and in each experiment, samples were taken from 3 fish. Then the average number of chloride cells from 10 samples was calculated to compare between changes in different treatments at similar times and changes in similar treatment at different times. The area of all chloride cells in 5 images was calculated from 10 images taken using the software, and the average size of these cells was obtained for each fish, and then for each treatment at each sampling time.

Measurements of plasma glucose level (mg/100 mL) by the colorimetric method were performed on a Technicon RA1000 Analyzer (USA) using a MAN commercial kit [Moron et al., 2003]. For this purpose, $100 \mu \mathrm{L}$ of plasma was used from each sample.

Statistical analysis. For data analysis, one-way ANOVA and Tukey's test were used in the SPSS-22 software. The significance of differences between the data of different groups was evaluated at the error level of 5\% (0.05). The MS Excel 2013 package was used to compose diagrams.

\section{Discussion of the results}

Glucose levels. The glucose level in the blood plasma of the control group (40 ppt) did not vary significantly during the experimental period $(P<0.05)$. The glucose level at 6 and 12 hours of exposure did not show any significant difference in any of the treatments. However, at $24 \mathrm{~h}$, the glucose level decreased significantly in the treatment of 5 ppt compared 
to the control group $(P<0.05)$. On day 7 , in addition to the salinity of $5 \mathrm{ppt}$, samples from $60 \mathrm{ppt}$ group $(P<0.05)$ had a significantly lower glucose level than at the control salinity. However, after two weeks (on day 14), no significant differences were observed between the different treatments $(P<0.05)$.

There was no significant difference between 60 and 20 ppt groups $(P>0.05)$ in separate treatments (within group). However, in the case of salinity of $5 \mathrm{ppt}$, the glucose level at $12 \mathrm{~h}$ of exposure, were significantly higher than at 6 and $24 \mathrm{~h}$. There was no significant difference between the values for other days (Fig. 1).

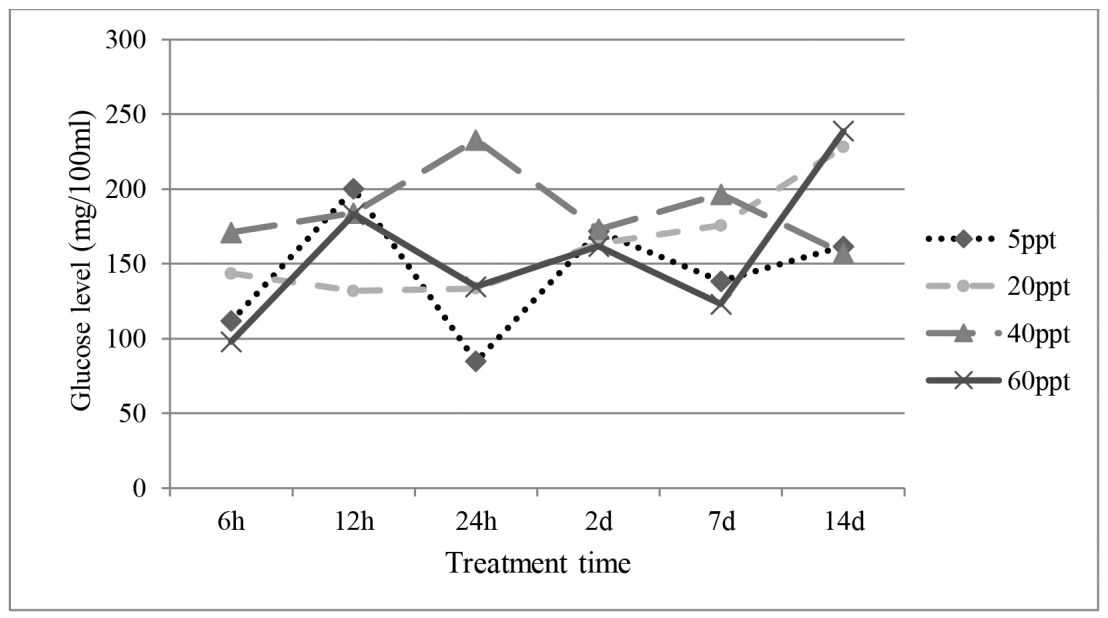

Fig. 1. Variations in blood plasma glucose level during different periods of salinity exposure

Рис. 1. Изменение уровня глюкозы в крови разных групп рыб в течение эксперимента

Changes in the number and density of MRCs in the filaments. Unlike the results from the 40 ppt group, which did not show a significant variation during the study, the number of MRCs (Fig. 2) in the hypo-osmotic and hyper-osmotic conditions showed significant differences throughout the experimental period. At the $5 \mathrm{ppt}$ salinity, the results indicated an initial increase in the number of MRCs up to day 2 and after that we observed a sudden increase in the number of MRCs, that led to a significant difference between the group of days 1 and 2 and the group of days 7 and $14(P<0.05)$ (Fig. 3).

In the second week, in addition to filamentous MRCs, lamellar MRCs were also observed at the salinity of $5 \mathrm{ppt}$, but they were much fewer in number compared to filamentous MRCs.

In the $60 \mathrm{ppt}$ group, the situation was almost similar to the $5 \mathrm{ppt}$ group: the average number of MRCs at this salinity also showed a rising trend, with the significant increase (difference) in average number of MRCs each day in comparison with the previous measurement, and for the entire period the number of MRCs showed a significant difference at any given time with other times $(P<0.05)$. The highest number of MRCs was observed at this salinity by the end of the observation period (Fig. 3). The increasing in number of MRCs at a salinity of $60 \mathrm{ppt}$ was limited to filamentary space. The changes in the $20 \mathrm{ppt}$ group were different from the results of the $60 \mathrm{ppt}$ group. In the $20 \mathrm{ppt}$ group, there was a significant difference between the numbers of ionocytes on all days of measurements $(P<0.05)$. The lowest number of MRCs was recorded at this salinity on day 14.

Changes in the area of MRCs due to salinity exposure. After exposing fish to different salinities, and studying changes in area of MRC due to this salinity, the highest increase in area was observed in fish of the 5 ppt group (Fig. 4). Therefore, in all the stages of sampling and studying the area of ionocytes in this salinity, there was a significant increase compared to the previous stage, and the area of the ionocytes at any given time showed a significant variation in this treatment compared to other times $(P<0.05)$. The highest mean area of MRC was recorded at this salinity on day 14 . In the case of $60 \mathrm{ppt}$ salinity, these changes were similar to those in the $5 \mathrm{ppt}$ group and albeit proved to be less severe. The gradient of changes at this salinity decreased from day 7 to 14 , but there was a significant variation between all sampling times in this treatment $(P<0.05)$. In spite of the upward trend in the $5 \mathrm{ppt}$ 

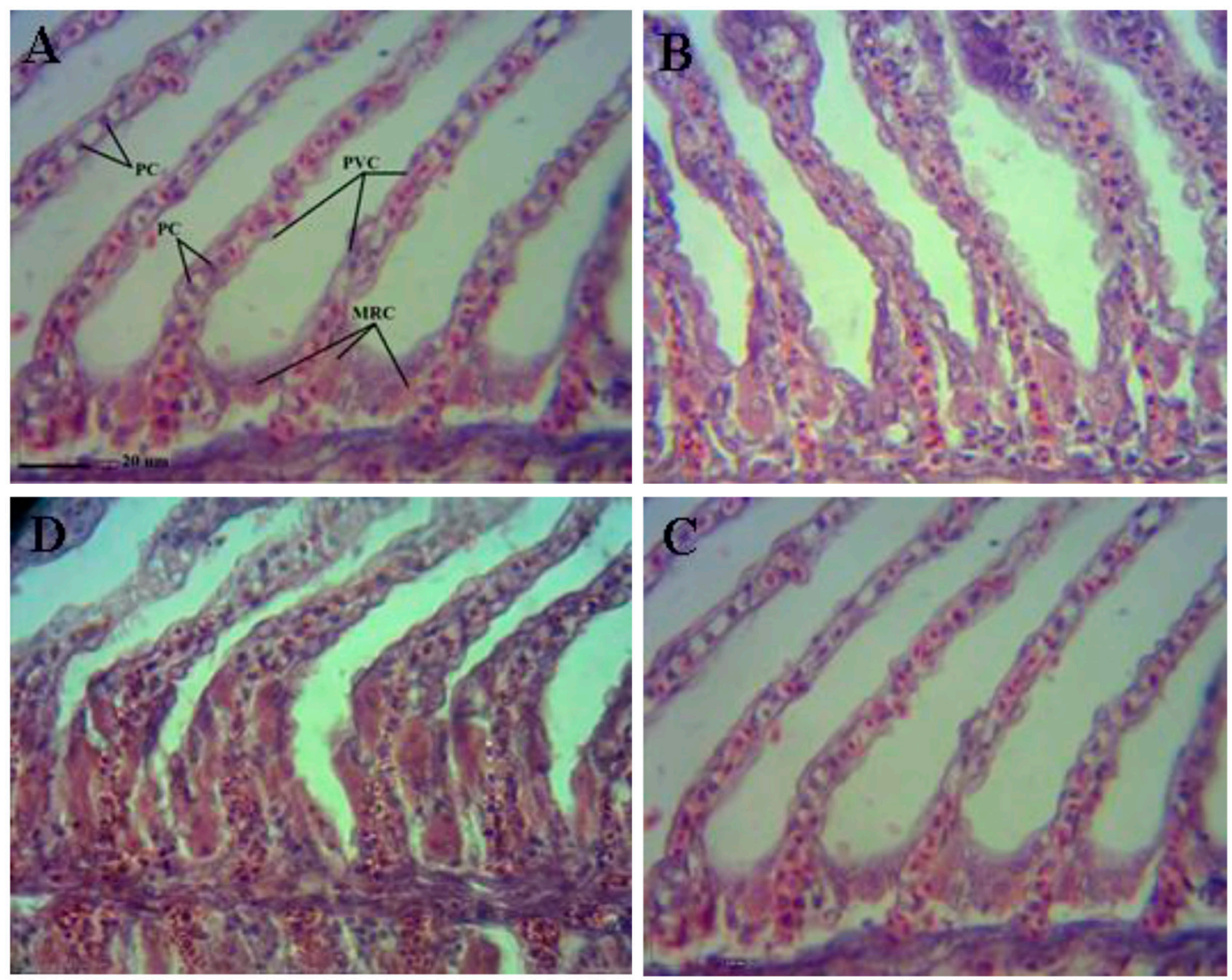

Fig. 2. (A) Gill lamellae of the control group: $P V C$, pavement cells; $P C$, pillar cells; $M R C$, mitochondria-rich cells. (B) Gill lamellae of the 5 ppt group. (C) Gill lamellae of the 20 ppt group. (D) Gill lamellae of the $60 \mathrm{ppt}$ group

Рис. 2. Жаберные ламеллы разных групп рыб: А (PVC - клетки мостовидного эпителия; $P C$ - стволовые клетки; $M R C$ - хлоридные (митохондриальные) клетки; $\mathbf{B}$ - группы рыб в эксперименте с соленостью 5 ppt; C - группы рыб в эксперименте с соленостью 20 ppt; D группы рыб в эксперименте с соленостью 60 ppt

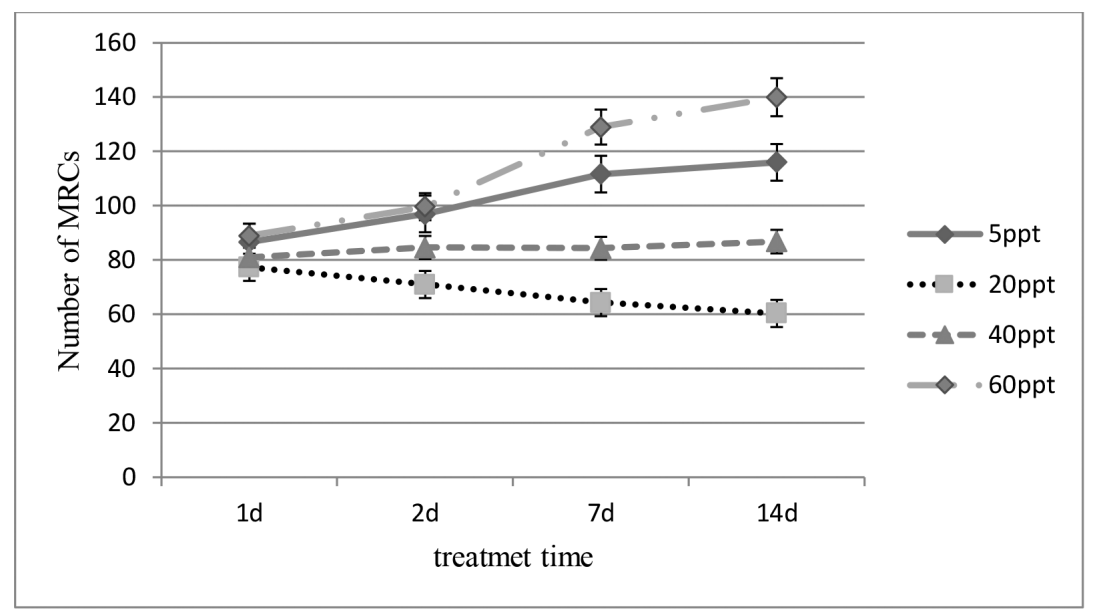

Fig. 3. Variations in the average number of mitochondria-rich cells in the filamentary space

Рис. 3. Изменение усредненного количества обогащенных митохондриальных (хлоридных) клеток в нитчатом пространстве

and $60 \mathrm{ppt}$ group, in the $20 \mathrm{ppt}$ group the area of the ionocytes progressed by the end of the experiment. The mean area of these cells was approximately the same on days 7 and 14, and 


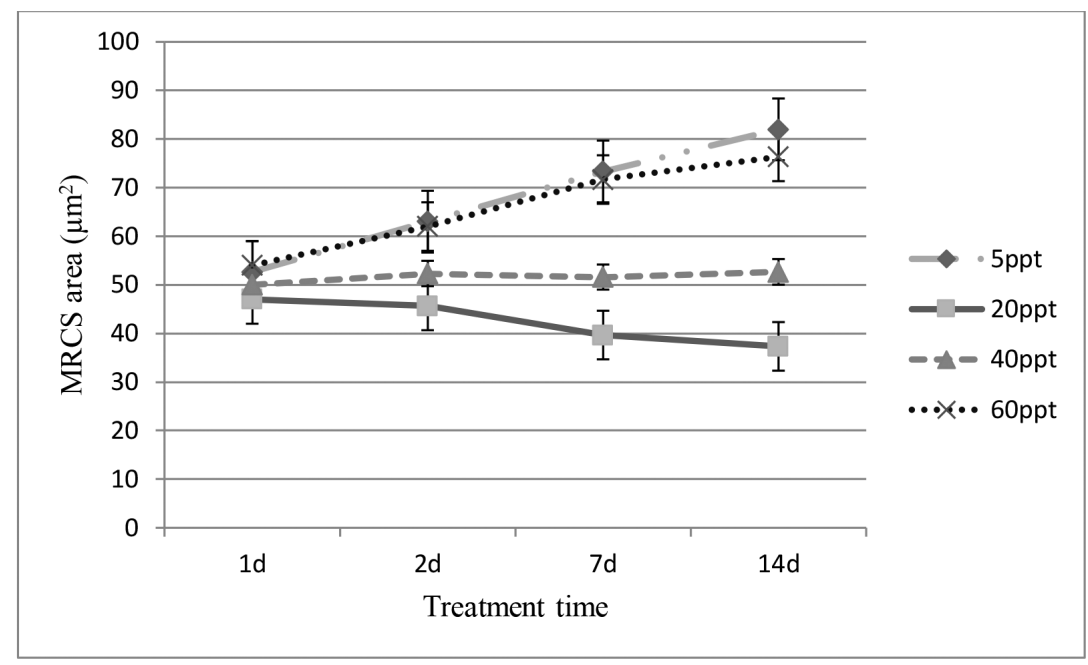

Fig. 4. Variations in the area of filamentous MRCs at different salinities $\left(\mu \mathrm{m}^{2}\right)$

Рис. 4. Изменения площади нитчатых хлоридных клеток в жабрах рыбы, выдержанной в воде при различной солености, $\mu \mathrm{m}^{2}$

on days 1 and 2 there was a significant variation between the two groups. There were no significant variations in the control group during the period $(P<0.05)$.

Plasma glucose level. In fish, plasma glucose is required to provide metabolic energy that is self-dependent on glycogen sources in the body [Pérez-Robles et al., 2012]. However, according to Fazio et al. [2013], in the case of Mugil cephalus, the stress related with variations in water salinity can change the production or consumption of metabolic energy. In this research, the glucose level in the 20 and 60 ppt groups, as well as in the control group, did not show significant variations at different stages. These results agree well with Movahedi's observations [2009].

Also, Laiz-Carrión et al. [2005] did not find any significant variation between plasma glucose levels in gilt-head bream for salinities similar to those mentioned above, which agrees with the results obtained in this study. However, in the case of salinity of $5 \mathrm{ppt}$, the glucose level at $12 \mathrm{~h}$ was significantly higher than the mean glucose at $24 \mathrm{~h}$. Although this result differed from the level in Acanthopagrus latus obtained at this salinity [Movahedinia, 2009], But it coincided with the results of other researchers, including Kelly et al. [1999]. They observed that Mylio macrocephalus blood glucose increased after exposure to a hyposmotic environment, indicating an increase in the displacement of energy sources to meet the increased metabolic needs of the organs involved in osmotic regulation, along with the apparent increases in metabolic activity of the osmotic arthropods [Mancera et al., 1993].

In addition to its role as an osmolyte, increase of the glucose might be a reflection of the stress response and needs more energy to maintain the balance of hydro-mineral in environments with higher salinity and temperature [Fiess et al., 2007].

Abundant and size of MRCs. So far, different studies about compromise cell and gill tissue in accordance with different salinities are provided. Sometimes the difference in the density of mitochondria-rich cells in a wide range of salinities is not reported. Among them, the study by Madsen et al. [1994] on striped bass (Morone saxatilis) and the study by Cioni et al. [1991] on tilapia (Oreochromis mosambicus) reported that the abundance of mitochondrial-rich cells after adaptation to sea water had no difference with fresh water, but their size increased. In contrast, several studies have shown that euryhaline fish adapted in freshwater to higher salinity, and an increase in the number of mitochondria-rich cells was shown [Avella et al., 1993; Altinok et al., 1998; Kelly et al., 1999; Zydlewski and McCormick, 2001]. Based on the results of the present study, MRC abundance in the $60 \mathrm{ppt}$ group increased rapidly so that during all the four times (on days 1,2, 7, and 14) there was a significant variation between the numbers of MRC in this salinity. Number of MRC in this 
salinity on the 1 st and 2 nd days with the 20 and 40 ppt groups and on the 7 th and 14th day showed a significant variation with all treatments. Movahedinia [2009] also has reported an increase in MRC number at 60 ppt. These changes also come with results of Laiz-Carrión et al. [2005]: they showed that the increased area of MRC is also significantly associated with a salinity of $60 \mathrm{ppt}$. It's also about $S$. husta at $60 \mathrm{ppt}$ : the area of MRC was significantly increased at each period of sampling, and at each time of sampling this size was significantly different with the previous days. Area of MRC in this salinity had a significant variation in salinity in all sampled hours. Other researchers also investigated the effect of a rapid transfer from sea water into a higher salinity on mitochondria-rich cells. Shahriari Moghadam et al. [2013] stated in their study that in Liza aurata chloride cells during transfer from a $12 \mathrm{ppt}$ salinity (salinity of the Caspian Sea) to a salinity $50 \mathrm{ppt}$ had a significant variation in number and size. In other words, the number and size of chloride cells in the $50 \mathrm{ppt}$ group was significantly larger than in the $12 \mathrm{ppt}$ group. Fielder et al. [2007] also reported the increase in size of the mitochondrial-rich cells in Pagrus auratus through compromise with a salinity of 45 ppt. These results show the important role of MRC in ion excretion under hyperosmotic conditions [Kelly et al., 1999].

On the other hand, the results of the experiment showed that similar changes in the number and area of MRCs occurred after exposure to hyposmotic environment. In the $5 \mathrm{ppt}$ group, the number of MRCs increased significantly on days 7 and 14, compared to the 1st and 2 nd days, and its level at all times had a significant variation compared with the control group. The area of MRCs was also heavily increased with salinity. Thus, the MRC peak for the entire period occurred on day 14. Also, the average area at this salinity from the 2 nd day till the end of the period had a significant variation relative to control group $(P<0.05)$. Varsamos et al. [2002] observed such a result when they exposed a sea bass (Dicentrarchus labrax) to a hyposomatic environment. In the case of Mugil cephalus and a species of Tilapia (Oreochromis mossambicus), it has been proven that as salinity increases, MRCs are often increased; its reduction (hyposomatic morbidity) usually increases the number of MRCs [Kelly et al., 1999].

In the 20 ppt group, the number of MRCs in the first two days of experiment was significantly lower than in the 60 and 5 ppt groups, and on the following days, variation were significantly lower than at the other salinities. The area of these cells in the treatment of $20 \mathrm{ppt}$, unlike the control group, also had an apparent downward trend, so that the data of the day 7 and day 14 was significantly lower than those on the 1 st and 2 nd days. The lowest mean number and area of MRCs in this experiment was for the $20 \mathrm{ppt}$ group. Movahedinia [2009] also recorded a significant decrease in the number of MRCs. Similarly, Fielder et al. [2007] by studying the Pagrus auratus filamental MRCs showed that the density of MRCs decreased significantly after exposure to a $20 \mathrm{ppt}$ salinity, which is consistent with the results of Laiz-Carrión et al. [2005]. Imsland et al. [2003] suggested that in case of reduction in the difference in ion concentrations between the external environment and body fluids at a salinity of $20 \mathrm{ppt}$, the need for the active removal of excess ions is reduced. Therefore, in an adaptive response, by decreasing the number and size of mitochondrial-rich cells, the number of enzymes and ionic carriers and, consequently, the activity of these cells decreases.

A research on the effect of salinity changes on morphological changes of gill chloride cells in Auratus pagrus showed the difference between the numbers of spherical and cylindrical chloride cells in the inter-lamellar spaces at different salinities. In the case of direct transfer of fish from a salinity of $30 \mathrm{ppt}$ to a salinity of $45 \mathrm{ppt}$, no change in the number of lamellar and filamentary chloride cells was recorded. However, the direct transfer of $A$. pagrus fish from a salinity of $30 \mathrm{ppt}$ to a salinity of $15 \mathrm{ppt}$ was accompanied by a decrease in the number of lamellar chloride cells. However, no changes were observed in the number of filamentary chloride cells. The results of the studies showed that different species use different strategies to adapt their MRCs to better meet the environment, so that these variations sometimes contradict one species in the same way from the same family in the same environment [Fielder et al., 2007]. 


\section{Acknowledgements}

This research was partially supported by the Fisheries Research Institute of Khuzestan Province Fisheries Department. We would like to thank professor Sawari for his expert advice and encouragement throughout this project and also our dear colleagues, engineers and laboratory assistants, as well as Reza Sahraeian, Nima Yazdi and Mohsen Heydari who greatly assisted the research.

\section{References}

Altinok, I., Galli, S.M., and Chapman, F.A., Ionic and osmotic regulation capabilities of juvenile Gulf of Mexico sturgeon, Acipenser oxyrinchus de sotoi, Comp. Biochem. Physiol., Part A, 1998, vol. 120, no. 4, pp. 609-616. doi 10.1016/S1095-6433(98)10073-9

Avella, M., Berhaut, J., and Bornancin, M., Salinity tolerance of two tropical fishes, Oreochromis aureus and $O$. niloticus. I. Biochemical and morphological changes in the gill epithelium, $J$. Fish. Biol., 1993, vol. 42, no. 2, pp. 243-254.

Baldisserotto, B., Mancera, J.M., and Kapoor, B.G., Fish Osmoregulation, Enfield, N.H.: Science Publ., 2007.

Cioni, C., De Merich, D., Cataldi, E., and Cataudella, S., Fine structure of chloride cells in freshwater- and seawater-adapted Oreochromis niloticus (Linnaeus) and Orechromis mossambicus (Peters), J. Fish. Biol., 1991, vol. 39, no. 2, pp. 197-209.

Evans, D.H., Piermarini, P.M., and Choe, K.P., The multifunctional fish gill: Dominant site of gas exchange, osmoregulation, acid-base regulation, and excretion of nitrogenous waste, Physiol. Rev., 2005, vol. 85, pp. 97-177. doi 10.1152/physrev.00050.2003

Fazio, F., Marafioti, S., Arfuso, F., Piccione, G., and Faggio, C., Influence of different salinity on haematological and biochemical parameters of the widely cultured mullet, Mugil cephalus, Mar. Freshwater Behav. Physiol., 2013, vol. 46, no. 4, pp. 211-218. doi 10.1080/10236244.2013.817728

Fielder, D.S., Allan, G.L., Pepperall, D., and Pankhurst, P.M., The effects of changes in salinity on osmoregulation and chloride cell morphology of juvenile Australian snapper, Pagrus auratus, Aquaculture, 2007, vol. 272, nos. 1-4, pp. 656-666. doi 10.1016/j.aquaculture.2007.08.043

Fiess, J.C., Kunkel-Patterson, A., Mathias, L., Riley, L.G., Yancey, P.H., Hirano, T., and Grau, E.G., Effects of environmental salinity and temperature on osmoregulatory ability, organic osmolytes, and plasma hormone profiles in the Mozambique tilapia (Oreochromis mossambicus), Comp. Biochem. Physiol., Part A, 2007, vol. 146, no. 2, pp. 252-264. doi 10.1016/j.cbpa.2006.10.027

Imsland, A.K., Gunnarsson, S., Foss, A., and Stefansson, S.O., Gill Na ${ }^{+}, \mathrm{K}^{+}$-ATPase activity, plasma chloride and osmolality in juvenile turbot (Scophthalmus maximus) reared at different temperatures and salinities, Aquaculture, 2003, vol. 218, no. 1-4, pp. 671-683. doi 10.1016/S0044-8486(02)00423-4

Jobling, M., Fish Bioenergetics, Netherlands: Springer-Verlag, 1994.

Karşi, A. and Yavuzcan Yildiz, H., Secondary stress response of Nile tilapia, Oreochromis niloticus, after direct transfer to different salinities, J. Tarim Bilimleri Dergisi., 2005, vol. 11, no. 2, pp. 139-141.

Kelly, S.P., Chow, I.N.K., and Woo, N.Y.S., Alterations in $\mathrm{Na}^{+}-\mathrm{K}^{+}$-ATPase activity and gill chloride cell morphometrics of juvenile black sea bream (Mylio macrocephalus) in response to salinity and ration size, Aquaculture, 1999, vol. 172, no. 3-4, pp. 351-367. doi 10.1016/S0044-8486(98)00505-5

Khuder, A.M., Majeed, M.F., and Al-Sawad, A.A., Comparative histological study of gills of two species in fresh water (Cyprinus carpio) and sea water fish (Otolithes ruber) of Iraq, Bas. J. Vet. Res., 2016, vol. 15, no. 1, pp. 332-339.

Kültz, D., Physiological mechanisms used by fish to cope with salinity stress, J. Exp. Biol., 2015, vol. 218, pp. 1907-1914. doi 10.1242/jeb.118695

Laiz-Carrión, R., Guerreiro, P.M., Fuentes, J., Canario, A.V.M., Martin Del Rio, M.P., and Mancera, J.M., Branchial osmoregulatory response to salinity in the gilthead sea bream, Sparus auratus, J. Exp. Zool., 2005, vol. 303A, no. 7, pp. 563-576. doi 10.1002/jez.a.183

Lisboa, V., Barcarolli, I.F., Sampaio, L.A., and Bianchini, A., Effect of salinity on survival, growth and biochemical parameters in juvenile Lebranch mullet Mugil liza (Perciformes: Mugilidae), Neotrop. Ichthyol., 2015, vol. 13, no. 2, pp. 447-452. doi 10.1590/1982-0224-20140122

Madsen, S.S., McCormick, S.D., Young, G., Endersen, J.S., Nishioka, R.S., and Bern, H.A., Physiology of seawater acclimation in the striped bass, Morone saxatilis (Walbaum), Fish Physiol. Biochem., 1994, vol. 13, no. 1, pp. 1-11. doi 10.1007/BF00004114

Mancera, J.M., Perez-Figares, J.M., and Fernandez-Llebrez, P., Osmoregulatory responses to abrupt salinity changes in the euryhaline gilthead sea bream (Sparus auratus L.), Comp. Biochem. Physiol., Part A, 1993, vol. 106, no. 2, pp. 245-250 doi 10.1016/0300-9629(93)90507-Z 
Marshall, W.S., Howard, J.A., Cozzi, R.R.F., and Lynch, E.M., $\mathrm{NaCl}$ and fluid secretion by the intestine of the teleost Fundulus heteroclitus: involvement of CFTR, J. Exp. Biol., 2002, vol. 205, pp. 745-758.

Moaddab, A.R., Khabazi, M., and Roosta, H., Determining the rate of salinity of Persian Gulf waters with the aid of satellite images and least squares method, Open J. Mar. Sci., 2017, vol. 7, no. 1, pp. 155-168. doi 10.4236/ojms.2017.71012

Moron, S.E., Oba, E.T., De Andrade, C.A., and Fernandes, M.N., Chloride cell responses to ion challenge in two tropical freshwater fish, the erythrinids Hoplias malabaricus and Hoplerythrinus unitaeniatus, J. Exp. Zool., 2003, vol. 298A, no. 2, pp. 93-104.

Movahedinia, A., Mechanisms of osmotic regulation in Acanthopagrus latus, study of ecophysiology, histology and ultrastructure of gills, Doctorate (Biol.) Dissertation, Marine Science and Technology University of Khorramshahr, 2009.

Pérez-Robles, J., Re, A.D., Giffard-Mena, I., and Diaz, F., Interactive effects of salinity on oxygen consumption, ammonium excretion, osmoregulation and $\mathrm{Na}^{+} / \mathrm{K}^{+}$-ATPase expression in the bullseye puffer (Sphoeroides annulatus, Jenyns 1842), Aquacult. Res., 2012, vol. 43, no. 9, pp. 1372-1383. doi 10.1111/j.1365-2109.2011.02940.x

Santos, D.M., Melo, M.R., Mendes, D.C., Rocha, I.K., Silva, J.P., Cantanhêde, S.M., and Meletti, P.C., Histological changes in gills of two fish species as indicators of water quality in Jansen Lagoon (São Luís, Maranhão State, Brazil), Int. J. Environ. Res. Public Health, 2014, vol. 11, no. 12, pp. 12927-12937. doi 10.3390/ijerph111212927

Shahriari Moghadam, M., Abtahi, B., Mosafer Khorjestan, S. and Bitaab, M.A., Salinity tolerance and gill histopathological alterations in Liza aurata Risso, 1810 (Actinopterygii: Mugilidae) fry, Ital. J. Zool., 2013, vol. 80, no. 4, pp. 503-509. doi 10.1080/11250003.2013.853326

Tahir, D., Shariff, M., Syukri, F., and Yusoff, F.M., Serum cortisol level and survival rate of juvenile Epinephelus fuscoguttatus following exposure to different salinities, Vet. World, 2018, vol. 11, no. 3, pp. 327-331. doi 10.14202/vetworld.2018.327-331

Uchida, K., Kaneko, T., Yamauchi, K., and Hirano, T., Morphometrical analysis chloride cell activity in the gill filaments and lamellae and changes in $\mathrm{Na}^{+}, \mathrm{K}^{+}$-ATPase activity during seawater adaptation in chum salmon fry, J. Exp. Zool., 1996, vol. 276, no. 3, pp. 193-200.

Varsamos, S., Diaz, J.P., Charmantier, G., Flik, G., Blasco, C., and Connes, R., Branchial chloride cells in sea bass (Dicentrarchus labrax) adapted to fresh water, seawater, and doubly concentrated seawater, J. Exp. Zool., 2002, vol. 293, no. 1, pp. 12-26. doi 10.1002/jez.10099

Zydlewski, J. and McCormick, S.D., Developmental and environmental regulation of chloride cells in young American shad, Alosa sapidissima, J. Exp. Zool., 2001, vol. 290, no. 2, pp. 73-87. doi 10.1002/jez.1037

Поступила в редакцию 14.09.2018 г. После доработки 8.10.2018 г. Принята к публикации 11.10.2018 2. 